\title{
Evaluation of Clinical Characteristics of Girls with Central Precocious Puberty at Diagnosis and During Treatment
}

\author{
Santral Puberte Prekokslu Kızların Tanı Anında ve Tedavi Süresince \\ Klinik Özelliklerinin Değerlendirilmesi \\ (1) Özlem KARA
}

Bursa Yüksek Intisas Education and Research Hospital, Department of Pediatric Endocrinology, Bursa, Turkey

\begin{abstract}
Objective: The aim of this study is to evaluate the anthropometric and clinical characteristics of girls with idiopathic central precocius puberty (CPP) at diagnosis, during and at the end of treatment.

Material and Methods: Sixty-one girls who were diagnosed with CPP and treated between January 2015 and December 2018 were included in the study. The anthropometric, clinical characteristics and laboratory test results at diagnosis, during and at the end of treatment were evaluated retrospectively.

Results: Mean age of the patients at diagnosis was $8.7 \pm 0.6$ years, bone age was $9.4 \pm 1.2$ years, target height was $158.5 \pm 5.2 \mathrm{~cm}$ and predicted height was $159.1 \pm 6.9 \mathrm{~cm}$. While 18 (30\%) patients presented with isolated thelarche, 11 (18\%) patients presented with menarche. At diagnosis, 28\% of the patients were obese and 25\% were overweight. The average treatment period was 2 years. The body mass index (BMI) increased during treatment $(\mathrm{p}<0.001)$, which was significant especially in the first two years of treatment $(p<0.001)$. In the first year of treatment, the ratio of the obese patients had increased to $36 \%$. During treatment, height growth rates were decreased $(p=0.02)$. However, the predicted height at the end of the study was $160.1 \pm 6.2 \mathrm{~cm}$ and there was no difference when compared to the height at diagnosis $(p>0.05)$.

Conclusion: Obese and overweight girls should be followed up for pubertal development. Awareness level of primary care physicians and pediatricians should be increased in order to identify the early puberty findings and provide appropriate guidance.
\end{abstract}

Key Words: Awareness, Idiopathic, Menarche, Obesity, Precocious puberty

Öz

Amaç: Idyopatik santral puberte prekokslu (SPP) kız olguların tanı anındaki, tedavi süresince ve tedavi bitimindeki antropometrik ve klinik özelliklerin değerlendirilmesi amaçlanmıştır.

Gereç ve Yöntemler: Çalışmaya Ocak 2015-Aralık 2018 yılları arasında SPP tanısı alan ve tedavisi tamamlanan 61 kız hasta çalışmaya alındı. Hastaların tanı anında, tedavi süresince ve bitiminde antropometrik, klinik ve laboratuvar özellikleri geriye dönük incelendi.

Bulgular: Hastaların tanı anındaki ortalama yaşı $8.7 \pm 0.6$ yll, kemik yaşı $9.4 \pm 1.2$ yll, hedef boy $158.5 \pm 5.2 \mathrm{~cm}$ ve öngörülen boy $159.1 \pm 6.9$ cm'di. Hastaların 18'i (\%30) izole telarş ile başvururken 11'i $(\% 18)$ menarş ile başvurduğu görüldü. Tanı anında hastaların \%28'i obez ve \%25'i fazla kiloluydu. Hastaların tedavi süresi ortalama 2 yıldı. Tedavi süresince hastaların vücut kitle indeksinde (VKI) artış saptandı $(p<0.001)$. Bu artış özellikle tedavinin ilk iki ylında belirgindi $(p<0.001)$. Tedavinin 1. yılında obez hasta oranı \%36'ya çıkmıștı. Tedavi süresince uzama hızlarında azalma saptandı ( $p=0.02)$. Ancak hastaların tedavi bitiminde öngörülen boyları $160.1 \pm 6.2 \mathrm{~cm}$ 'di ve tanı anına göre farkllık yoktu ( $p>0.05)$.

Sonuç: Obez ve fazla kilolu kız çocukları pubertal gelişim açısından yakın takip edilmelidir. Özellikle erken puberte bulgularının tanınması ve uygun yönlendirme yapılması için bu konuda birinci basamak hekimlerinin ve pediatristlerin farkındallık düzeyinin artırıması gerekmektedir.

Anahtar Sözcükler: Farkındalık, Idyopatik, Menarş, Obezite, Puberte prekoks 


\section{INTRODUCTION}

Central precocious puberty (CPP) is the development of secondary sex characteristics before the age of 8 in girls and 9 in boys due to early activation of hypothalamus-pituitarygonad axis (1). Although the incidence of CPP varies in different populations, its incidence is less than 2/10000 in females and $5 / 10000$ in males (2). Nowadays, long-acting gonadotropin releasing hormone $(\mathrm{GnRH})$ analogues are preferred in treatment of CPP due to their safe, effective applications and good patient compliance. GnRH analogues are in use since 1981 (3). The aim of this treatment is to delay epiphyseal closure by slowing bone maturation and to slow down / stop the progression of secondary sex characteristics by suppressing the pituitarygonad axis (4). Although not frequent, systemic complaints such as headache, hot flashes, emotional and behavioral problems, seborrhea and acne can be seen. Approximately 10 to 15\% of the patients have reported local side effects such as pain at injection site, rashes, sterile abscesses (5). Long-term side effects on reproductive system, bone health and body fat mass have been evaluated (6-8). There are many studies investigating the BMI in particular. It is not clear which mechanisms cause predisposition to overweight or obesity. Yet, there are studies showing that CPP treatment has different effects on BMI (9-12).

The aim of this study was to evaluate the anthropometric, clinical and laboratory findings of the girls diagnosed with CPP at the time of diagnosis, during and after treatment.

\section{PATIENTS and METHODS}

A total of 61 female patients who were diagnosed with idiopathic CPP and treated in department of pediatric endocrinology in Bursa Yuksek Ihtisas Education and Research Hospital between January 2015 and December 2018 were included in this sectional study. The Local Ethics Committee of the hospital approved the study protocol (nr: 2011-KAEK-25 2019/02-03) and the study was performed in accordance with Declaration of Helsinki. Patients who presented to the hospital with any signs of puberty were evaluated for CPP. The patient was diagnosed with CPP if; a) onset of breast development was before the age of 8, b) the growth rate was increased and the bone age was at least 1 year ahead of the calendar age, c) basal luteinizing hormone $(\mathrm{LH})$ level was $0.3 \mu \mathrm{lU} / \mathrm{ml}$ and/or LH level after luteinizing hormone-releasing hormone $(\mathrm{LHRH})$ stimulation was $\geq 5 \mu \mathrm{lU} / \mathrm{ml}(13,14)$. Cranial magnetic resonance imaging $(\mathrm{MRI})$ was performed in all patients to exclude cranial organic pathologies. Patients with brain tumor, history of cranial radiotherapy, congenital adrenal hyperplasia and hypothyroidism were excluded from the study.

Height, body weight (BW), BMI and standard deviation (SD) scores were calculated before treatment. Tanner staging was used to determine the puberty stage of the patients (15).
Bone age was evaluated. The genetic height was calculated according to mother and father height. According to their presentations, patients were divided into groups as: breast development (thelarche), pubic and /or axillary hair (pubarche) and menstrual bleeding (menarche).

All patients were started with $\mathrm{GnRH}$ analogues [(Lucrin depot $3.75 \mathrm{mg}$ ( (leuprolide acetate) Decapeptyl depot 3.75 mg® (triptorelin acetate)]. The treatment was administered intramuscularly/subcutaneous every 28 days. The patients were evaluated every 3 months. Puberty findings, height, BW, $\mathrm{BMI}$, growth rates were recorded. GnRH analogue test was performed to evaluate the pituitary-gonad axis suppression in patients with rapid clinical progression under treatment. Peak $\mathrm{LH}$ level $<5 \mu \mathrm{lU} / \mathrm{ml}$ showed suppression (16). Bone age was evaluated annually. The treatment was discontinued when the calendar age of the patients was 11 and/or bone age was 12 (17-19). Height, BW, BMI, puberty stage and bone age of the patients were recorded at the end of treatment. Duration of the treatment was calculated.

Height measurement was recorded in cm by using Harpenden Stadiometer. Body weight was measured on an empty stomach without top clothing and recorded in $\mathrm{kg}$. Body mass index was calculated by weight $(\mathrm{kg}) /$ height $(\mathrm{m})^{2}$ formula. Height, BW, BMI scores and standard deviation were calculated. Patients with a body mass index of 85th-95th percentile were calculated as overweight and those with $\geq 95 p$ were obese.

Target height (TH) was calculated by using the (mother height + father height)-13/2 formula (20). Bone age was evaluated by using the Greulich and Pyle atlas (21). The predicted height $(\mathrm{PH})$ was calculated according to Bayleu and Pinneau method (22).

SPSS-21 software package (IBM Corp. Released 2012. IBM SPSS Statistics for Windows, Version 21.0. Armonk, NY, USA) was used for statistical analyses. Data was mean \pm SD. Minimum and maximum values were given between parantheses. In the analysis of the data, the variance analysis of repeated measures and Friedman test were used. In case of significance, Wilcoxon signed rank test and paired t-test were used. $\mathrm{p}<0.05$ was accepted for statistical significance.

\section{RESULTS}

A total of 61 females with idiopathic CPP were included in the study. The mean presentation age of the patients was $8.7 \pm 0.6$ years. Twenty-nine (47\%) patients presented with telarche and pubarche, 18 (30\%) with thelarche, 11 (18\%) with menarche and $3(5 \%)$ with pubarche clinics (Figure 1). According to puberty staging, $46 \%$ of the patients were Tanner stage 3, $28 \%$ were stage 2 and $26 \%$ were stage 4 . The pretreatment average BW of the patients was $31.2 \pm 5.6 \mathrm{~kg}$, average height $131.9 \pm 4.0 \mathrm{~cm}$, mean BMl $17.8 \pm 2.5 \mathrm{~kg} / \mathrm{m} 2$. At diagnosis, $28 \%$ of the patients were obese and $25 \%$ were overweight. The pretreatment mean bone age was $9.4 \pm 1.2$ years, target height 


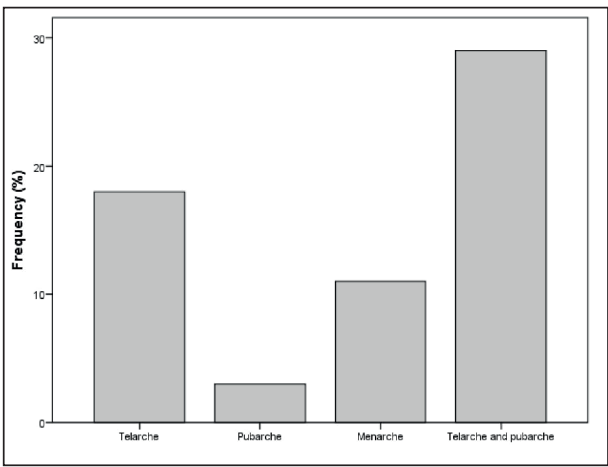

Figure 1: Presentation of Patients.

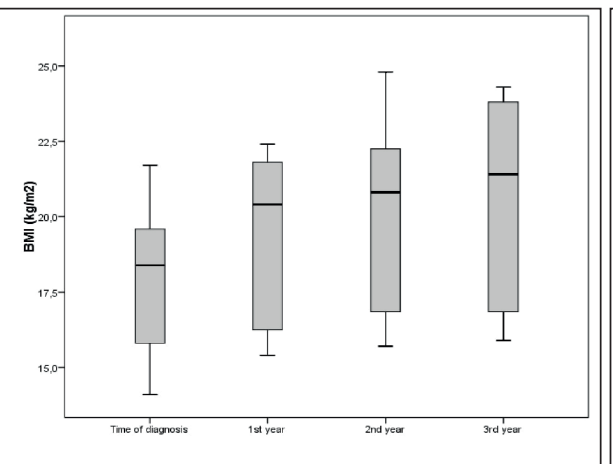

Figure 2: The changes in BMl levels according to treatment duration.

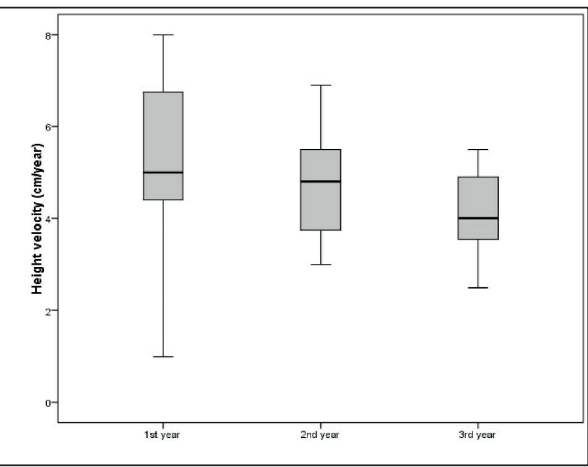

Figure 3: Height velocity of patients during treatment. was $158.5 \pm 5.2 \mathrm{~cm}, \mathrm{PH}$ was $159.1 \pm 6.9 \mathrm{~cm}$. The pretreatment mean follicle stimulating hormone $(\mathrm{FSH})$ levels were $4.9 \pm 2.1$ $\mu \mathrm{lU} / \mathrm{ml}, \mathrm{LH} 1.9 \pm 1.8 \mu \mathrm{lU} / \mathrm{ml}$ and estradiol $\left(E_{2}\right) 40.0 \pm 17.7 \mathrm{pg} /$ $\mathrm{ml}$. Average duration of treatment was 2 years. The clinical and laboratory findings of the patients before treatment are given in Table I. BMI was found to be increased during treatment $(p<0.001)$. The rate of the obese patients had increased to $36 \%$ at the end of the first year of treatment. The changes in BMl levels according to treatment duration are shown in Figure 2. There was a significant increase in BMl levels during treatment when compared to the pretreatment term $(p<0.001)$. BMl continued to increase during the ${ }^{1} \mathrm{st}$ and ${ }^{2} \mathrm{nd}$ years of treatment $(p=0.01)$. Even though the increase continued in the ${ }^{3} \mathrm{rd}$ year of treatment, it was not statistically significant $(p>0.05)$.

During treatment, the growth rates were $5.3 \pm 1.8,4.8 \pm 1.2$ and $4.0 \pm 0.9 \mathrm{~cm}$ for the ${ }^{1} \mathrm{st},{ }^{2} \mathrm{nd}$ and ${ }^{3} \mathrm{rd}$ years of treatment, respectively. The growth rate decreased during treatment $(p=0.02)$ (Figure 3).

The bone age of the patients was $10.2 \pm 0.9,10.9 \pm 0.9$ and $11.5 \pm 0.8$ years for the ${ }^{1} \mathrm{st}$, ${ }^{2} \mathrm{nd}$ and ${ }^{3} \mathrm{rd}$ years of treatment, respectively. The predicted height was $159.2 \pm 6.2,160.8 \pm 5.5$ and $160.1 \pm 6.2 \mathrm{~cm}$ for the ${ }^{1} \mathrm{st},{ }^{2} \mathrm{nd}$ and ${ }^{3} \mathrm{rd}$ years of treatment, respectively. There was no significant difference between the bone age and the predicted height during treatment ( $p>0.05$ ). The clinical characteristics of the patients during treatment are given in Table II.

\section{DISCUSSION}

The onset of puberty in girls is clinically often thelarche. However, pubic hair may grow rarely before or together with thelarche (23). In the study, $47 \%$ of the patients presented with both thelarche and pubarche findings. In addition, 18\% of the patients presented with menarche. The pubertal status was $46 \%$ Tanner stage 3, 28\% stage 2 and 26\% stage 4, respectively. This situation may be explained by the low level of awareness of the families about pubertal status. Most of the patients present to the hospital after the onset of menarche, which shows the seriousness of the condition. Early menarche
Table I: Clinical and Laboratory Characteristics of Patients.

\begin{tabular}{|c|c|}
\hline Number of patients * & $61(100)$ \\
\hline $\begin{array}{l}\text { Presentation of patients * } \\
\text { Telarche } \\
\text { Pubarche } \\
\text { Telarche and pubarche } \\
\text { Menarche }\end{array}$ & $\begin{array}{l}19(30) \\
3(5) \\
29(47) \\
11(18)\end{array}$ \\
\hline Age at diagnosis (mean year $\pm s d$ ) & $8.7 \pm 0.6$ \\
\hline Bone age (mean year $\pm s d)$ & $9.4 \pm 1.2$ \\
\hline Target height (cm) & $158.5 \pm 5.2$ \\
\hline Predicted height $(\mathrm{cm})$ & $159.1 \pm 6.9$ \\
\hline Body weight (kg) & $31.2 \pm 5.6$ \\
\hline Body weight sd & $0.8 \pm 1.0$ \\
\hline Height (cm) & $131.9 \pm 4.0$ \\
\hline Height sd & $0.6 \pm 0.7$ \\
\hline BMI $\left(\mathbf{k g} / \mathbf{m}^{2}\right)$ & $17.8 \pm 2.5$ \\
\hline BMI sd & $0.8 \pm 1.0$ \\
\hline FSH (mlU/ml) & $4.9 \pm 2.1$ \\
\hline LH (mlU/ml) & $1.9 \pm 1.9$ \\
\hline E2 (pg/ml) & $40.0 \pm 17.7$ \\
\hline $\begin{array}{l}\text { Duration of the treatment * } \\
1 \text { year } \\
2 \text { years } \\
3 \text { years }\end{array}$ & $\begin{array}{c}14(23) \\
38(62) \\
9(15) \\
\end{array}$ \\
\hline
\end{tabular}

Sd:Standard deviation, BMI:Body mass index, $\boldsymbol{F S H}$ : Follicle stimulating hormone, $\boldsymbol{L} \boldsymbol{H} ;$ Luteinizing hormone, $\boldsymbol{E}_{2}$ :Estradiol, *: n(\%)

has been associated with obesity, hypertension, type 2 diabetes, ischemic heart disease, stroke, estrogen-dependent cancer, and cardiovascular mortality $(24,25)$. Biological, psychosocial and long-term health effects play a role in timing of puberty. In studies conducted in 1960s, the age range of onset of normal puberty has been determined as $8-13$ years in girls (23). However, cross-sectional studies performed in the last 20 years show that onset of puberty is shifting to earlier ages. This situation can be explained by better health, nutrition and hygiene of people (26). The age of presentation of our patients was 8.7 \pm 0.6 years (7.5-9.8 years) and those presented with menarche in particular were in the older age group $(p<0.001)$. 
Table II:Clinical characteristics of patients during treatment.

\begin{tabular}{|c|c|c|c|c|c|}
\hline & Time of diagnosis & $1^{\text {st }}$ year & $2^{\text {nd }}$ year & $3^{\text {rd }}$ year & $p$ \\
\hline $\begin{array}{l}\text { Bone age } \\
\text { (mean year } \pm s d)\end{array}$ & $9.4 \pm 1.2$ & $10.2 \pm 0.9$ & $10.9 \pm 0.9$ & $11.5 \pm 0.8$ & $<0.001^{\mathrm{a}, \mathrm{b}, \mathrm{c}}$ \\
\hline Predicted height (cm) & $159.1 \pm 6.9$ & $159.3 \pm 6.2$ & $160.8 \pm 5.3$ & $160.1 \pm 6.2$ & $>0.05^{a, b, c}$ \\
\hline Body weight (kg) & $31.2 \pm 5.6$ & $36.5 \pm 6.6$ & $41.3 \pm 8.5$ & $44.3 \pm 9.6$ & $<0.001^{\mathrm{a}, \mathrm{b}, \mathrm{c}}$ \\
\hline Body weight sd & $0.7 \pm 1.0$ & $0.8 \pm 1.11$ & $0.9 \pm 1.13$ & $0.7 \pm 1.1$ & $>0.05^{a, b, c}$ \\
\hline Height (cm) & $131.9 \pm 4.0$ & $137.7 \pm 4.3$ & $142.6 \pm 5.2$ & $145.8 \pm 5.1$ & $<0.001^{a, b, c}$ \\
\hline Height sd & $0.6 \pm 0.7$ & $0.7 \pm 0.7$ & $0.4 \pm 0.8$ & $0.1 \pm 0.7$ & $>0.05^{a, b, c}$ \\
\hline Body mass index $\left(\mathrm{kg} / \mathrm{m}^{2}\right)$ & $17.8 \pm 2.5$ & $19.16 \pm 2.8$ & $20.1 \pm 3.1$ & $20.6 \pm 3.3$ & $\begin{array}{l}<0.001^{a, b} \\
>0.05^{c}\end{array}$ \\
\hline Body mass index sd & $0.8 \pm 1.1$ & $1.1 \pm 0.9$ & $1.0 \pm 0.8$ & $0.7 \pm 1.0$ & $>0.05^{a, b, c}$ \\
\hline Height velocity (cm/year) & & $5.3 \pm 1.8$ & $4.8 \pm 1.2$ & $4.1 \pm 0.9$ & $<0.05^{\mathrm{a}, \mathrm{b}, \mathrm{c}}$ \\
\hline
\end{tabular}

a:Comparison between 1st and 2nd years, ${ }^{b}$ : Comparison between 1st and 3rd years, c: Comparison between 2nd and 3rd years standard deviation, sd: Standard deviation, parameters are shown as mean $\pm s d$

Before treatment, $28 \%$ of the patients were obese and $25 \%$ were overweight. Although it has been reported that the increase in body fat percentage in childhood is associated with early puberty, some studies have suggested that $\mathrm{GnRH}$ analogue therapy causes obesity.

$\mathrm{BMl}$ of the patients showed that $36 \%$ of the patients were obese and $23 \%$ were overweight in the 1st year of treatment. There is a significant increase in rate of obesity after treatment. In a study by Cruz et al. which have included 121 girls with CPP, the rate of the obese or overweight patients has been reported as $50.4 \%$ and at the end of the 1st year, they have found that this rate has increased to $70 \%$ (8). In another study including 176 girls with CPP, an increase in BMI has been detected after treatment, especially in patients who had a normal weight before treatment (27). In a study that has evaluated the body composition, it has been reported that body fat percentage has increased and lean body mass percentage has decreased during treatment (28). A similar study has shown that $\mathrm{GnRH}$ has caused significant increase in total fat mass without changing BMI (9). In contrast with these studies, there are many studies showing that $\mathrm{GnRH}$ treatment does not change BMl and BMl can be decreased with treatment $(10,12,29)$.

Although a decrease in growth rates of patients was detected, there was no change in predicted heights. In a study that included 47 girls with CPP who were treated with $\mathrm{GnRH}$ and whose adult heights were evaluated, it has been shown that the adult height of the patients is taller than the predicted height (29). In a similar study that evaluated the adult height of 87 girls, it has been shown that adult height increase is significant in children younger than 5-6 years (10). In this study, the predicted and adult heights of the patients were not evaluated.

To conclude, obese and overweight girls should be monitored carefully for pubertal development. In order to identify the early puberty findings and provide appropriate guidance, awareness level of primary care physicians and pediatricians should be increased. Patients treated for CPP should be followed up for the increase in BMl.

\section{REFERENCES}

1. Sorensen K, Mouritsen A, Aksglaede L, Hagen CP, Mogensen SS, Juul A. Recent secular trends in pubertal timing: implications for evaluation and diagnosis of precocious puberty. Horm Res Paediatr 2012;77:137-4

2. Teilmann G, Pedersen CB, Jensen TK, Skakkebaek NE, Juul A. Prevalence and incidence of precocious pubertal development in Denmark: an epidemiologic study based on national registries. Pediatrics 2005;116:1323-8.

3. Crowley WF Jr, Comite F, Vale W, Rivier J, Loriaux DL, Cutler GB Jr. Therapeutic use of pituitary desensitization with a long-acting LHRH agonist: a potential new treatment for idiopathic precocious puberty. J Clin Endocrinol Metab 1981;52:370-2.

4. Fuld K, Chi C, Neely EK. A randomized trial of 1- and 3-month depot leuprolide doses in the treatment of central precocious puberty. J Pediatr 2011;159:982-7.

5. Carel JC, Eugster EA, Rogol A, Ghizzoni L, Palmert MR, ESPELWPES GnRH Anologs Consensus Conference Group. Consensus statement on the use of gonodotropin-releasing hormone analogs in the children. Pediatrics 2009;123:e752-62.

6. Cassio A1, Bal MO, Orsini LF, Balsamo A, Sansavini S, Gennari M, et al. Reproductive outcome in patients treated and not treated for idiopathic early puberty: long-term results of a randomized trial in adults. J Pediatr 2006;149:532-6.

7. Assa A, Weiss M, Aharoni D, Mor A, Rachmiel M, Bistritzer T. Evaluation of bone density in girls with precocious and early puberty during treatment with $\mathrm{GnRH}$ agonist. J Pediatr Endocrinol Metab 2011;24:505-10.

8. Zurita Cruz JN, Díaz Rodríguez I, Nishimura Meguro E, Villasis Keever MÁ, De Jesús Rivera Hernández A, Garrido Magaña E. Change in body mass index among girls with precocious puberty under treatment. Arch Argent Pediatr 2016;114:143-5.

9. Chiocca E, Dati E, Baroncelli GI, Mora S, Parrini D, Erba P, Bertelloni S. Body Mass Index and Body Composition in Adolescents Treated with Gonadotropin-Releasing Hormone Analogue Triptorelin Depot for Central Precocious Puberty: Data at Near Final Height. Neuroendocrinology 2009;89:441-7.

10. Pasquino AM, Pucarelli I, Accardo F, Demiraj V, Segni M, Di Nardo R. Long-Term Observation of 87 Girls with Idiopathic Central Precocious Puberty Treated with Gonadotropin-Releasing Hormone Analogs: Impact on Adult Height, Body Mass Index, Bone 
Mineral Content, and Reproductive Function. J Clin Endocrinol Metab 2008, 93:190-5.

11. Palmert MR, Mansfield MJ, Crowley WF Jr, Crigler JF Jr, Crawford JD, Boepple PA. Is Obesity an Outcome of Gonadotropin-Releasing Hormone Agonist Administration? Analysis of Growth and Body Composition in 110 Patients with Central Precocious Puberty. J Clin Endocrinol Metab1999;84:4480-8.

12. Arrigo T, De Luca F, Antoniazzi F, Galluzzi F, Segni M, Rosano $M$, et al. Reduction of baseline body mass index under gonadotropinsuppressive therapy in girls with idiopathic precocious puberty. Eur J Endocrinol 2004;150:533-7.

13. Neely EK, Eilson DM, Lee PA, Stene M, Hintz RL. Spontaneous serum gonodotropin concentrations in the evaluation of precocious puberty. J Pediatr 1995;127:47-52.

14. Kandemir N, Demirbilek H, Ozon A, Gonc N, Alikasifoglu A. GnRH stimulation test in precocious puberty;single sample is adequate for diagnosis and dose adjustment. Horm Res 2009;72:336.

15. Marshall WA, Tanner JM. Variations in the pattern of pubertal changes in girls. Arc Dis Child 1969;44:291-303.

16. Nelly EK, Hintz RL, Wilson DM, Lee PA, Gautier T, Argente J, et al. Normal ranges for immunochemiluminometric gonadotropin assays. J Pediatr 1995;127:40-6.

17. Arrigo T, Cisternino M, Galluzzi F, Bertelloni S, Pasquino AM, Antoniazzi F, et al . When stop GnRH analog therapy:The experience of the Italian Study Group for physiopathology of puberty. J Pediatr Endocrinol Metab 2000;13:759-64.

18. Partsch C-J, Sippell WG, and German Decapeptyl Study Group. Treatment of central precocious puberty :Lessons from a 15 years prospective trial. J Pediatr Endocrinol Metab 2000;13:747-58.

19. Antoniazzi F, Arrigo T, Cisternino M, Galluzzi F, Bertelloni S, Pasquino AM, et al. End results in central precocious puberty with $\mathrm{GnRH}$ analog treatment: The data of the Italian Study Group for physiopathology of puberty. J Pediatr Endocrinol Metab 2000;13:773-80.
20. Tanner JM, Goldstein H, Whitehouse RH. Standards for children's height at ages 2-9 years allowing for heights of parents. Arch Dis Child 1970;45:755-62.

21. Greulich WW, Pyle SI. Radiographic atlas of skeletal development of the hand and wrist. 2nd ed. Stanford, CA: Stanford University Press; 1959

22. Bayley N, Pinneau SR. Tables for predicting adult height from skeletal age: revised for use with the Greulich-Pyle hand standards. J Pediatr 1952;40:423-41.

23. Parent AS, Teilmann G, Juul A, Skakkebaek NE, Toppari J, Bourguignon JP. The timing of normal puberty and the age limits of sexual precocity: variations around the world, secular trends, and changes after migration. Endocr Rev 2003;24: 668-93.

24. Lakshman R, Forouhi NG, Sharp SJ, Fraser GE. Early age at menarche associated with cardiovascular disease and mortality. J Clin Endocrinol Metab 2009; 94: 4953-60.

25. Prentice P, Viner RM. Pubertal timing and adult obesity and cardiometabolic risk in women and men: a systematic review and meta-analysis. Int J Obes (Lond) 2013;37:1036-43.

26. Willemsen RH, Elleri D, Williams RM, Ong KK, Dunger DB. Pros and cons of GnRHa treatment for early puberty in girls. Nat Rev Endocrinol 2014;10:352-63.

27. Aguiar AL, Couto-Silva AC, Vicente EJ, Freitas IC, Cruz T, Adan L. Weight evolution in girls treated for idiopathic central precocious puberty with $\mathrm{GnRH}$ analogues. I Pediatr Endocrinol Metab 2006;19:1327-34.

28. Boot AM, De Muinck Keizer-Schrama S, Pols HA, Krenning EP, Drop SL. Bone mineral density and body composition before and during treatment with gonadotropin-releasing hormone agonist in children with central precocious and early puberty. J Clin Endocrinol Metab 1998;83:370-3.

29. Poomthavorn P, Suphasit R, Mahachoklertwattana P. Adult height, body mass index and time of menarche of girls with idiopathic central precocious puberty after gonadotropin-releasing hormone analogue treatment. Gynecological Endocrinology 2011;27: 5248. 